\title{
Potassium and Manganese Fertilization and the Effects on Millet Seed Yield, Seed Quality, and Forage Potential of Residual Stalks
}

\author{
Maru Kipleting Kering 1*, Cyril Broderick² \\ ${ }^{1}$ Agricultural Research Station, Virginia State University, Petersburg, VA, USA \\ ${ }^{2}$ Agricultural Research Station, Delaware State University, Dover, DE, USA \\ Email: *mkering@vsu.edu
}

How to cite this paper: Kering, M.K. and Broderick, C. (2018) Potassium and Manganese Fertilization and the Effects on Millet Seed Yield, Seed Quality, and Forage Potential of Residual Stalks. Agricultural Sciences, 9, 888-900.

https://doi.org/10.4236/as.2018.97061

Received: May 10, 2018

Accepted: July 27, 2018

Published: July 30, 2018

Copyright $\odot 2018$ by authors and Scientific Research Publishing Inc. This work is licensed under the Creative Commons Attribution International License (CC BY 4.0).

http://creativecommons.org/licenses/by/4.0/

\begin{abstract}
Millets are important natural grain source for wild and game birds and the domesticated varieties are good sources of grain for human and livestock nutrition as well as summer forage. Unlike sorghum, millet seed has less anti-nutrient factors and is a better choice for animal feed formulations. Pearl millet is an example of such millets and has both forage- and grain-type varieties. However, opportunities exist for dual use of millet for grain and residue for forage. In this study two millets: Pennisetum glaucum (L.) R. Br. (Pearl millet var. TifGrain 102) and Panicum ramosum (L.) (Browntop millet) were evaluated for their response to potassium $(\mathrm{K})$ and manganese $(\mathrm{Mn})$ fertilizer. The experiment was a randomized complete block with treatments in a split-split arrangement. Potassium and $\mathrm{Mn}$ were supplied as $\mathrm{K}$ fertilizer (0-0-60) and manganese sulfate $\left(\mathrm{MnSO}_{4} \cdot 2 \mathrm{H}_{2} \mathrm{O}\right)$, respectively. Potassium and $\mathrm{Mn}$ fertilizer rates and their interaction with each other and variety had no effect on determined parameters. TifGrain 102 grain yield averaged at 5900 $\mathrm{kg} \cdot \mathrm{ha}^{-1}$ was significantly greater than $4680 \mathrm{~kg} \cdot \mathrm{ha}^{-1}$ obtained for Browntop millet. While grain oil contents were similar, Browntop grain had greater contents of crude proteins. And except for K, Browntop seed had greater contents of all determined macro-and micronutrients. Residual stalks of Browntop had greater forage crude protein, total digestible nutrient (TDN) and lower acid detergent fiber (ADF). Browntop residual material had greater quantities of estimated net energy for growth (NEG), lactation (NEL), maintenance (NME). While TifGrain 102 residual stalks had greater contents of $\mathrm{P}$ and $\mathrm{K}$, it had significantly lower contents of $\mathrm{Ca}, \mathrm{Mg}$ and $\mathrm{S}$ compared to Browntop. Overall, while these two millets have shown good potential for dual use, Browntop may offer a better choice for high quality seed and residual stalks for forage.
\end{abstract}




\section{Keywords}

Millet, Potassium, Manganese, Seed Residual-Stalks, Forage Quality

\section{Introduction}

Millets are an important grain and pasture crop, and pearl millet is produced as a cereal grain in an estimated area of 26 million hectares worldwide [1] is also used for forage. It does better than other cereal grains like corn, wheat, and rice in poor soils and under dry conditions [2]. In the US, pearl millet which occupies an estimate of over 600,000 hectares of land [3] is an important summer forage grass [4]. While other warm season grasses, like sorghum are available, the use of millet removes the risk associated with prussic acid poisoning common in sorghums. In addition, millet seeds have less anti-nutrient factors and are better choices for feed formulation in small ruminant, poultry, hog, and swine operations. While both forage and seed-type varieties exist, some varieties may be produced as a dual crop after seed harvest; left-over stalks can be hayed and used as forage. In the wild, millets are a critical source of grain for wild game and non-game birds. Massive losses of millet seed in the field are attributed to these grain feeding birds. Domesticated millet seed can be used as feed/or feed supplements in swine and poultry production, and has also been fed directly to wild and pet birds by bird enthusiasts. Pearl millets is one such millet that has high protein and essential amino acid content and is used as feed in poultry and hog operations [2] [5]. The quality of seed used for feed in these systems may vary depending on fertilizer management strategies during production. Changes in global climate conditions that include increased temperature and carbon dioxide level are expected to affect crop performance. For example increased temperature has been reported to reduce seed carbohydrate and oil content in some chili pepper plants [6] and correlations between mean annual temperature and leaf mineral element concentrations in several plant genera have been shown [7]. These changes will affect the nutritive quality of crops and therefore directly affecting human and animal food/feed.

Mineral element fertilizer application improves both the quantity and quality of harvestable plant parts like forage and seeds. While there are numerous studies on macronutrients requirements of pearl and other millets [8] [9], there is limited information on micronutrient elements requirements and their effects on seed and stalk forage quality. Potassium (K), though not a constituent of proteins, is a key element in metabolic transport and protein synthesis, and its availability may improve the protein content of the grain. There are reports that $\mathrm{K}$ affects both nitrate uptake and assimilation and improves $\mathrm{N}$ use efficiency in crops [10] [11]. Potassium also improves protein and amino acid content in seeds [12] [13], and it plays a role in moisture stress tolerance [14] [15]. Manganese, a second nutrient element in this study is a micronutrient required by all 
plant species for growth and reproduction [16]. It is a component of the water splitting protein complex PS II and superoxide dismutase (MnSOD), and it is involved in enzymes activation of critical metabolic pathways [16]. Manganese is cation activator of Acetyl-CoA carboxylase [17], an enzyme involved in the first committed step in fatty acid synthesis. The level of $\mathrm{Mn}$ in plant tissues may therefore affect oil and protein proportions in seed. Sufficient Mn in plants may affect lignin and phenol biosynthesis, and can reduce fungal diseases [18]. Manganese may also increase biomass accumulation due to its role in PSII constitution. Sufficient $\mathrm{Mn}$ in forage is important for animals due to Mn's role inbone development and reproductive growth [19].

Because studies show that mineral elements in the leaf are remobilized to other plant organs including developing seed during leaf senescence [20] [21] Our hypothesis is that fertilization may result in increased leaf and stalk nutrient content some of which will be remobilized to developing seed. Improved plant performance from increased nutrient status could improve seed and forage quality of residual stalks and have a direct effect on the performance of animals utilizing seeds and residual stalk as feed source. Therefore, $\mathrm{K}$ and Mn fertilization may increase both macro and micronutrient concentration in vegetative material and seeds in millets and have an effect on protein, oil and mineral element composition of seed and residual stalks. Also with increasing atmospheric $\mathrm{CO}_{2}$, ambient temperatures, and frequencies of below average precipitations, drought tolerant crops like millet may be a crop of choice to supply needed forage and to supplement corn in meeting the needs of grain-based animal operations in the eastern US. The objectives of this study are to determine the effect of potassium $(\mathrm{K})$ and manganese $(\mathrm{Mn})$ fertilizer on millet. Effects on: 1) seed yield and quality; 2) left-over stalk forage quality were evaluated.

\section{Materials and Methods}

\subsection{Study Site Experiment Layout and Fertilization Approaches}

The study was carried out at two locations: Virginia State University and Delaware State University. Millet varieties used were; pearl millet var. TifGrain 102 and Browntop millet (var. not specified). The soil at Randolph Farm (Virginia State University) is a Bourne fine sandy loam (mixed, semi-active, thermic Typic Fragiudulfs). The selected area at Virginia State University had been under soybean and had received N, P, and $\mathrm{K}$ fertilizer levels based on soil analyses recommendations. Delaware soils are Greenwich loam soils (a coarse, loamy, mixed, semiactive, mesic, Typic Hapludult). The site used at Delaware State University had been maintained under grass over the last two seasons.

The study was laid out as a three factor experiment with treatments in a split-split arrangement replicated four times. Millet variety was assigned to the main plot, $\mathrm{K}$ fertilizer level $\left(0,40,80\right.$ or $\left.120 \mathrm{~kg} \cdot \mathrm{ha}^{-1}\right)$ in the sub-plot and Mnfertilizer $\left(0,10\right.$, or $\left.25 \mathrm{~kg} \mathrm{Mn} \mathrm{ha}^{-1}\right)$ as sub-subplot treatment. The subplot that was $9 \mathrm{~m}$ in length was split into $3 \mathrm{~m}$ sub-subplot experimental units. Seeds were drilled to a 
depth of $10-15 \mathrm{~m}$ musing a seed drill with a row spacing of $38 \mathrm{~cm}$. Potassium and $\mathrm{Mn}$ fertilizer were applied as potash $\left(\mathrm{K}_{2} \mathrm{O}\right)$ and manganese sulfate $\left(\mathrm{MnSO}_{4} \cdot 2 \mathrm{H}_{2} \mathrm{O}\right)$, respectively. Nitrogen $\left(60 \mathrm{~kg} \mathrm{~N} \mathrm{ha}^{-1}\right)$ was applied post-emergence to all plots.

\subsection{Vegetative Growth, Seed Harvest and Residual Stalk Sub-Sampling}

Height measurement where determined before boot stage and three random height were obtained in each plot to determine plot average height. At seed maturity, TifGrain 102 seed heads were harvested manually from a randomly selected area that encompass the two middle rows in each experimental plot. In Browntop, whole plants with seeds were harvested in randomly selected area encompassing two middle rows. The harvested seed heads of TifGrain 102 and harvested crop in Browntop were dried and seed shelled. Representative stalks of TifGrain 102 were obtained from the area where seed where harvested. For Browntop after seed was shelled, the residual material was obtained and stored for further processing. Residual stalk (Mainly stem, dried leaves and leaf sheath) were further dried, ground and stored pending needed analysis. Based on the experimental plot seed yield, total seed yield $\left(\mathrm{kg} \cdot \mathrm{ha}^{-1}\right)$ was calculated.

\subsection{Sample Analysis}

A subsample of the seed was ground and protein, oil and mineral element content determined. A sample of the ground residual stalk material was analyzed for crude protein $(\mathrm{CP})$, acid detergent fiber (ADF), and total digestible nutrient (TDN) as well as $\mathrm{P}, \mathrm{K}, \mathrm{Mg}, \mathrm{Ca}$, and $\mathrm{S}$. Seed oil content was determined using the Association of Analytical Chemists ether extraction method [22]. Seed and residual stalk protein content were calculated based on total nitrogen determined by combustion using methods described by the Association of Analytical Chemists [23]. Crude protein was calculated as total nitrogen $\times 6.25$. For both forage and seed, ground material was digested in nitric acid and elemental composition determined using inductively couple plasma (ICP) atomic absorption spectroscopy [24]. Acid detergent fiber was determined as described by ANKOM techniques [25]. Forage energy contents were calculated using ADF and TDN values based on prediction equations developed by Pennsylvania States University and as used by the Waypoint Analytical (Waypoint Analytical, Inc., Memphis $\mathrm{TN})$.

\subsection{Statistical Analysis}

Data was analyzed using the Proc Mix Model procedures in SAS [26]. Year, location, replication and their interactions were considered random and variety, potassium and manganese fertilizer rates were fixed effects. Significance was determined at $\mathrm{p} \leq 0.05$. The PDIFF function of the LSMEANS procedure was used to compare means. 


\section{Results and Discussion}

\subsection{Vegetative Growth}

Most crop plants take 90 to 120 days from seeding to flowering and maturity. Unlike most plants, the millet species that were used in these experiments germinated in a few days and grew speedily to flower in four to five weeks. The mature crop grew from seeds and seedlings to a fully mature crop that was ready in as early as eight weeks after planting.

Growth responses of TifGrain 102 and Browntop millet to potassium and manganese fertilization are shown in Figure 1 and Figure 2, respectively. In Figure 1 , it is clear that plant response to potassium was maximal around $80 \mathrm{~kg} \cdot \mathrm{ha}^{-1}$. At $100 \mathrm{~kg} \mathrm{~K} \mathrm{ha}^{-1}$, the plants were shorter. For the three levels of manganese applied, the rate of $10 \mathrm{~kg} \mathrm{Mn} \mathrm{ha}{ }^{-1}$ provided the best growth response and plants were well anchored and sturdy. Plants receiving $25 \mathrm{~kg} \mathrm{Mn} \mathrm{ha}^{-1}$ did not grow as tall but were fully productive as those treated with $10 \mathrm{~kg} \mathrm{Mn} \mathrm{ha}^{-1}$.

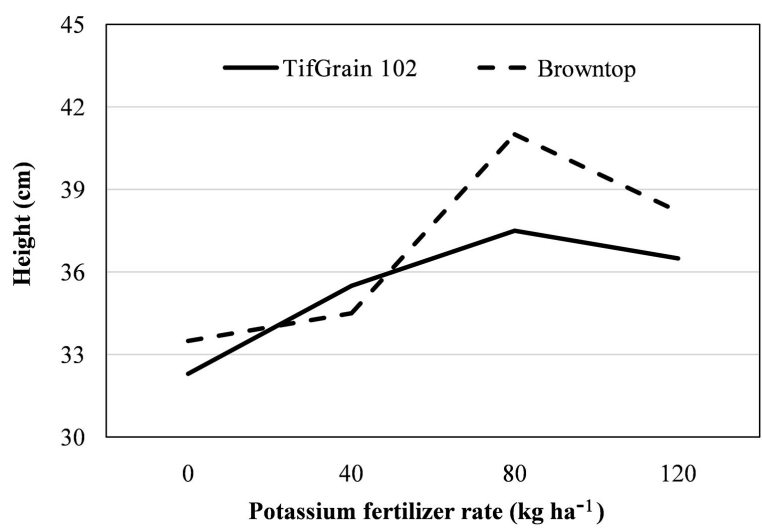

Figure 1. Responses of TifGrain 102 and Browntop millet varieties to potassium fertilization are shown. Both TifGrain 102 and Browntop millet types grew best at $80 \mathrm{~kg} \cdot \mathrm{ha}^{-1}$.

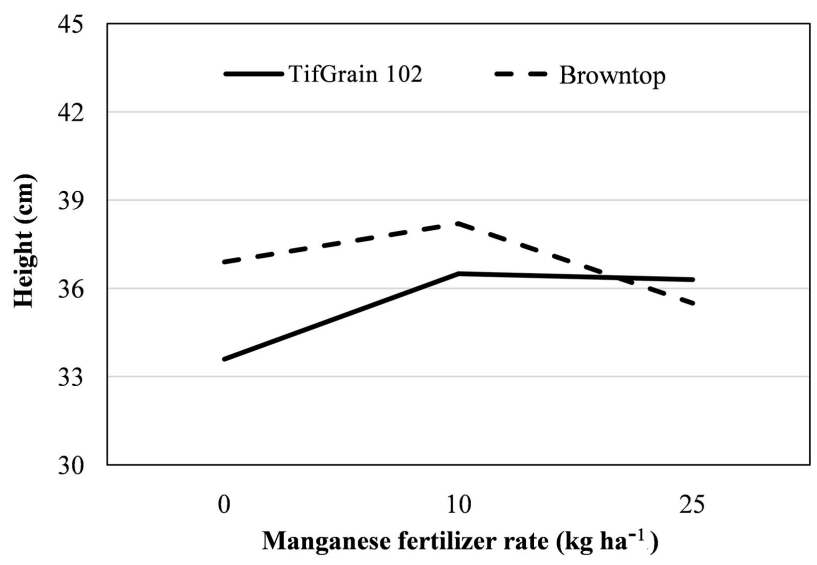

Figure 2. The best responses of TifGrain 102 and Browntop to the micronutrient element manganese were at $10 \mathrm{~kg} \cdot \mathrm{ha}^{-1}$. 


\subsection{Seed Yield}

Seed yield was affected, and there were differences between varieties $(\mathrm{p}<$ 0.0001). While there were effects of $\mathrm{K}$ and $\mathrm{Mn}$ fertilizer rates, on plant growth, seed yields among the treatments were not significantly different. Across fertilizer rates, TifGrain 102 produced the greatest seed yield at $5900 \mathrm{~kg} \cdot \mathrm{ha}^{-1}$ against that of Browntop millet averaged at $4684 \mathrm{~kg} \cdot \mathrm{ha}^{-1}$ (Table 1). The TifGrain 102 yields were comparable to those reported for other pearl millet varieties in Alabama and Nebraska [9]. The yields while comparable to that of irrigated crop in Nebraska, it was greater than that of non-irrigated crop [27]. TifGrain 102 yield was however greater than the $500 \mathrm{~kg} \cdot \mathrm{ha}^{-1}$ produced by pearl millet cultivar CIVT (composite Inter-Varietal de Tarna) grown in a tropical environment (Powell and Fussell, 1993). Browntop yield were slightly greater than the $3500-4000 \mathrm{~kg} \cdot \mathrm{ha}^{-1}$ reported earlier [28] in southern India. Because Browntop has an indeterminate inflorescence, seeds that matured earlier are lost before harvest time. In addition, wild birds had a preferential feeding on Browntop and caused yield losses of up to $30 \%$ (no data shown). This preference may be linked to the high nutritional quality of seed as shown in result below. In fact it was found that in mourning doves, $50 \%$ of ingested seeds was Browntop millet [29]. Browntop is reported to contribute $20 \%-25 \%$ of water and terrestrial birds diet [30].

\subsection{Seed Protein and Oil Content}

There was significant difference $(\mathrm{p}<0.01)$ between varieties in the amount of seed crude protein (CP). Potassium and Mn fertilizer did not affect the protein levels in seed. Also three- and two-way interactions were not significant. Browntop millet had the greater seed protein content at $133 \mathrm{~g} \cdot \mathrm{kg}^{-1}$ compared to TifGrain 102 (Table 2). However, TifGrain 102 seed oil content at $50 \mathrm{~g} \cdot \mathrm{kg}^{-1}$ was significantly greater than $46.7 \mathrm{~g} \cdot \mathrm{kg}^{-1}$ found in Browntop seed (Table 1). The amount of crude protein is similar to that reported for other millets and comparable to that of wheat and sorghum but greater than that reported for corn [31]. While crude protein and oil contents in this study are lower than that reported for some pearl millet hybrids in Canada [32], protein content are within the range $88-209 \mathrm{~g} \cdot \mathrm{kg}^{-1}$ previously reported for pearl millet [33]. TifGrain $102 \mathrm{mil}$ let has been reported before where it is indicated to have comparable total metabolizable energy (TME) and higher protein content than corn [34]. While results have shown that pearl millet seed underperforms compared to corn and sorghum for starter broilers, it was better than the two as a finishing ration [35] and whole millet seed increased gizzard size and broilers achieved equivalent weights to those feed maize and soybean meal [36]. Pearl millet was reported to substitute corn with insignificant effect on pig feed intake and growth during the first two weeks of the experiment [37]. The same study reported that essential amino acid profile of conventional millet was shown to be better than that of corn and sorghum and its protein content is comparable to that of sorghum and wheat and higher than that of corn. Similar superior amino acid profile with 
Table 1. Seed yield and seed protein and oil content in two millet varieties produced at Randolph Farm, Ettrick, VA.

\begin{tabular}{cccc}
\hline Variety & $\begin{array}{c}\text { Seed yield } \\
\left(\mathrm{kg} \cdot \mathrm{ha}^{-1}\right)\end{array}$ & \multicolumn{2}{c}{$\begin{array}{c}\text { Content in the seed } \\
\left(\mathrm{g} \cdot \mathrm{kg}^{-1}\right)\end{array}$} \\
\hline & & Protein & Oil \\
TifGrain 102 & $5900 \mathrm{a}$ & $89.0 \mathrm{~b}$ & $50.0 \mathrm{a}$ \\
Browntop & $4680 \mathrm{~b}$ & $133.1 \mathrm{a}$ & $46.7 \mathrm{~b}$ \\
$\mathrm{SE}^{\dagger}$ & 235 & 2.2 & 0.79 \\
\hline
\end{tabular}

${ }^{\dagger}$ Standard error of the mean.

Table 2. Mineral element content of TifGrain 102 pearl and Browntop millet seeds.

\begin{tabular}{|c|c|c|c|}
\hline Mineral element & TifGrain 102 & Browntop millet & $\mathrm{SE}^{\dagger}$ \\
\hline \multicolumn{4}{|c|}{$\mathrm{g} \cdot \mathrm{kg}^{-1}$} \\
\hline Phosphorus & $2.90 \mathrm{~b}$ & $3.59 \mathrm{a}$ & 0.06 \\
\hline Potassium & $4.61 \mathrm{a}$ & $3.40 \mathrm{~b}$ & 0.10 \\
\hline Magnesium & $1.15 \mathrm{~b}$ & $1.78 \mathrm{a}$ & 0.04 \\
\hline Calcium & $0.14 \mathrm{~b}$ & $0.26 \mathrm{a}$ & 0.02 \\
\hline Sulphur & $0.99 \mathrm{~b}$ & $1.46 \mathrm{a}$ & 0.02 \\
\hline \multicolumn{4}{|c|}{$\mu \mathrm{g} \cdot \mathrm{g}^{-1}$} \\
\hline Iron & $44.8 \mathrm{~b}$ & $56.3 \mathrm{a}$ & 3.96 \\
\hline Manganese & $16.5 \mathrm{~b}$ & $25.0 \mathrm{a}$ & 0.88 \\
\hline Zinc & $31.8 \mathrm{~b}$ & $41.6 a$ & 1.25 \\
\hline Copper & $4.9 \mathrm{~b}$ & $7.5 a$ & 0.25 \\
\hline
\end{tabular}

${ }^{\dagger}$ Standard error of the mean.

high amounts of essential amino acid is reported for pearl millet and suggest its potential as source of nutritious grain for both animals and man [2].

\subsection{Seed Macro- and Micro-Nutrient Content}

Three way and all two-way interactions were not significant for both macro and micro-nutrient content. Macronutrient content was affected by millet variety ( $\mathrm{p}$ $<0.0001$ ). Apart from $\mathrm{K}$, all analyzed macronutrients showed greater content in Browntop millet and least contents in TifGrain 102. The Brown top had P content was $25 \%$ greater than TifGrain 102 and had $84 \%$ greater Ca content (Table 2). All micronutrients analyzed showed greater amounts in Browntop. Browntop seed had $25 \%$ more iron $(\mathrm{Fe})$ and up to $56 \%$ more $\mathrm{Mn}$ in the seed compared to those in TifGrain 102 (Table 2). In general these millet had greater content of $\mathrm{Mg}, \mathrm{Fe}, \mathrm{Mn}$ and $\mathrm{Zn}$ that that of corn [38]. The levels of macro and micro-nutrients are important for use of grain for animal feed. Unlike in corn-fed 
chick, serum levels of $\mathrm{P}, \mathrm{Zn}$ and Fe were higher in pearl millet fed chicks and with less porous bones, a finding attributed to lower levels of phytate in pearl millet seed [39]. Because it is comparable to corn in other forage attributes pearl millet may be beneficial in animal feed formulation because its phytate content is less than $10 \%$ that of corn and has high micronutrient content and beneficial phenolic compounds [39].

\subsection{Residual Stalks Crude Protein, ADF and TDN and Energy Content}

There was significant $(\mathrm{p}=0.02)$ difference between varieties on residual stalk $\mathrm{CP}$. There was no interaction between variety, $\mathrm{K}$ and $\mathrm{Mn}$ fertilizer rate. Also two way interactions were not significant. For Browntop, residual stalks crude protein of $56.7 \mathrm{~g} \cdot \mathrm{kg}^{-1}$ was $16 \%$ higher than that found in TifGrain 102 stalks (Table 3). Crude protein content in TifGrain 102 residues were comparable to those found in another pearl millet variety previously [40]. Despite CP being below the reported minimum of $70 \mathrm{~g} \cdot \mathrm{kg}^{-1}$ for ruminant maintenance [41], the two were higher than those reported for corn stalk in other findings [42] and was close to $63 \mathrm{~g} \cdot \mathrm{kg}^{-1}$ reported for corn stalk silage [43].

No three-way and two-way interaction was observed for ADF content in the residual stalks. However, there was significant difference $(\mathrm{p}<0.01)$ existed between TifGrain 102 and Browntop residual stalks ADF content. TifGrain 102 residual stalks had higher ADF content than Browntop. The ADF content of $396.3 \mathrm{~g} \cdot \mathrm{kg}^{-1}$ (TifGrain 102) and $385.3 \mathrm{~g} \cdot \mathrm{kg}^{-1}$ (Browntop) were lower than 462 $\mathrm{g} \cdot \mathrm{kg}^{-1}$ reported for corn stalk (Smith et al., 1991). While three- and two-way interaction were not significant, there was significant $(\mathrm{p}<0.01)$ variety effect on residual stalks TDN. Browntop TDN content at $594.2 \mathrm{~g} \cdot \mathrm{kg}^{-1}$ was greater than that found in TifGrain 102.

Compared to that of TifGrain 102, total metabolizable energy (ME), net energy for lactation (NEL), net energy for maintenance (NEM), and net energy for gain (NEG) were significantly greater in Browntop residual material (Table 3). Superiority of Browntop in energy content is not surprising since CP and TDN are greater and ADF lower in Browntop compared to TifGrain 102. Both millets had greater magnitudes for ME, NEM, NEG compared to maize stover used to feed cattle [43].

\subsection{Residual Stalks Mineral Element Composition}

The three-way interaction and all two-way interactions were not significant. Only varieties showed significant $(\mathrm{p}<0.05)$ differences in the concentration of mineral elements. TifGrain 102 residues had greater contents of $\mathrm{P}$ and $\mathrm{K}$ while Browntop had greater quantities of $\mathrm{Mg}, \mathrm{Ca}$, and $\mathrm{S}$ (Table 4). At a concentration of $>1.4 \mathrm{~g} \mathrm{P} \mathrm{kg}^{-1}$ for both millet varieties, $\mathrm{P}$ concentrations were above the $1.2 \mathrm{~g} \cdot \mathrm{kg}^{-1}$ reportedly needed for growth in ruminants [44]. An indication that this residual material may provide sufficient $P$ if used for ruminant feed. 
Table 3. Crude protein, ADF, TDN and Energy value of residual stalks of TifGrain 102 and Browntop millet.

\begin{tabular}{|c|c|c|c|}
\hline Forage attribute & TifGrain 102 & Browntop millet & $\mathrm{SE}^{\dagger}$ \\
\hline \multicolumn{4}{|c|}{$\mathrm{g} \cdot \mathrm{kg}^{-1}$} \\
\hline $\mathrm{CP}$ & $48.8 \mathrm{~b}$ & $56.7 \mathrm{a}$ & 4.6 \\
\hline $\mathrm{ADF}$ & $396.3 \mathrm{a}$ & $385.3 b$ & 3.36 \\
\hline TDN & $581.9 \mathrm{~b}$ & $594.2 \mathrm{a}$ & 3.74 \\
\hline \multicolumn{4}{|c|}{$\mathrm{g} \cdot \mathrm{kg}^{-1}$} \\
\hline NEL & $1.31 \mathrm{~b}$ & $1.34 \mathrm{a}$ & 0.01 \\
\hline NEM & $1.25 \mathrm{~b}$ & $1.29 \mathrm{a}$ & 0.01 \\
\hline NEG & $0.68 \mathrm{~b}$ & $0.72 \mathrm{a}$ & 0.01 \\
\hline $\mathrm{ME}$ & $2.11 \mathrm{~b}$ & $2.15 \mathrm{a}$ & 0.01 \\
\hline
\end{tabular}

${ }^{\dagger}$ Standard error of the mean.

Table 4. Mineral element content of residual stalks of pearl and Browntop millet crop.

\begin{tabular}{cccc}
\hline Mineral element & TifGrain 102 & Browntop millet & $\mathrm{SE}^{\dagger}$ \\
\hline $\mathrm{P}$ & $2.5 \mathrm{a}$ & $\mathrm{g} \cdot \mathrm{kg}^{-1}$ & \\
$\mathrm{~K}$ & $38.9 \mathrm{a}$ & $1.5 \mathrm{~b}$ & 0.12 \\
$\mathrm{Mg}$ & $2.5 \mathrm{~b}$ & $25.9 \mathrm{~b}$ & 1.55 \\
$\mathrm{Ca}$ & $7.4 \mathrm{~b}$ & $5.9 \mathrm{a}$ & 0.19 \\
$\mathrm{~S}$ & $1.6 \mathrm{~b}$ & $9.0 \mathrm{a}$ & 0.26 \\
\hline
\end{tabular}

${ }^{\dagger}$ Standard error of the mean.

\section{Conclusion}

While quality residual stalks may not be produced at the expense of seed quality and yield, some report have indicate that there exist some pearl millet varieties that will produce high grain yield and residual stalk of high forage quality. These two have seed quality that may substitute corn in animal feed formulation. And while residual stalk forage quality attributes may not meet feed requirement for high milk production in dairy animal and body gain in beef, they are sufficient to meet the maintenance needs of dry mature animals. Lack of fertilizer response may be due previous land-use fertilizer management that could have left soil with near sufficient nutrient levels. Also reported high nutrient use efficiencies of these millets may affect fertilizer response. While no response was observed on seed yields and seed and forage quality attributes in this study, studies on marginal low fertility soils where millets have superior performance to alternatives like corn need to be studied. It is possible that while such marginal areas have been shown to give appreciable millet yield, addition of such critical nutrients may enhance crop production and residual stalk forage quality. More re- 
search involving animal may be needed to fully understand the economic returns of dual-systems where grain and forage are desired.

\section{Acknowledgements}

We want to thank Delmarva Land Grant Institution Collaborative Research Seed Funding Program for a grant that made this research possible. We are also grateful to farm crew from both Virginia and Delaware State Universities for data collection and associated field operations. This article is a contribution of Virginia State University, Agricultural Research Station (Journal Article Series No. 342), with the collaboration of the College of Agriculture and Related Sciences at Delaware State University.

\section{Conflicts of Interest}

The authors declare no conflicts of interest regarding the publication of this paper.

\section{References}

[1] Andrews, D.J. and Bramer-Cox, P. (1994) Breeding Cultivars for Sustainable Crop Production in Low-Input Dry Land Agriculture in the Tropics. In: Buxton, D.A., Ed., International Crop Science. CSSA, Madison, WI, 211-222.

[2] Ejeta, G., Hassen, M.M and Mertz, E.T. (1987) In Vitro Digestibility and Amino Acid Composition of Pearl Millet (Pennisetum typhoides) and Other Cereals. PNAS, 84, 6016-6019. https://doi.org/10.1073/pnas.84.17.6016

[3] Andrews, D.J., Hanna, W.W, Rajewski, J.F. and Collins V.P. (1996) Advances in Grain Pearl Millet: Utilization and Production Research. In: Janick, J., Ed., Progress in New Crops, ASHS Press, Alexandria, VA, 170-177.

[4] Marshalls, M.A., Laurlault, L.M. and Trostle, C. (2012) Millets for Forage and Grain in New Mexico and West Texas. Cooperative Extension Services, Guide A-417, New Mexico State University, Las Cruces.

[5] Haydon, K.D. and Hobbs, S.E. (1991) Nutrient Digestibilities of Soft Winter Wheat, Improved Triticale Cultivars, and Pearl Millet for Finishing Pigs. Journal of Animal Science, 69, 719-725. https://doi.org/10.2527/1991.692719x

[6] Pagamas, P. and Nawata, E. (2007) Effect of High Temperature during the Seed Development on Quality and Chemical Composition of Chili Pepper Seeds. Japanese Journal of Tropical Agriculture, 51, 22-29.

[7] Hans, W.X., Fang, J.F., Reich, P.B., Ian Woodward, F. and Wang, Z.H. (2011) Biogeography and Variability of Eleven Mineral Elements in Plant Leaves across Gradients of Climate, Soil and Plant Functional Type in China. Ecology Letters, 14, 788-796. https://doi.org/10.1111/j.1461-0248.2011.01641.x

[8] Bartiono, A., Christianson, C.B. and Klaij M.C. (1993) The Effect of Crop Residue and Fertilizer Use on Pearl Millet Yields in Niger. Fertilizer Research, 34, 251-258. https://doi.org/10.1007/BF00750571

[9] Obeng,E., Cebert, E., Singh, P.B., Ward. R., Nyochembeng, L.M. and Mays, D.A. (2012) Growth and Grain Yield of Pearl Millet (Pennisetum glaucum) Genotypes at Different Levels of Nitrogen Fertilization in the Southeastern United States. Journal 
of Agricultural Science, 4,155-163. https://doi.org/10.5539/jas.v4n12p155

[10] Fixen, F.E., and West, F.B. (2002) Nitrogen Fertilizers: Meeting Contemporary Challenges. AMBIO: A Journal of the Human Environment, 31, 169-176. https://doi.org/10.1579/0044-7447-31.2.169

[11] Anjana, Umar, S. and Iqbal, M. (2009) Effect of Applied Potassium in Increasing the Potential for N Assimilation in Spinach (Spinacea oleracea L.). e-ifc No. 20, June 2009.

[12] Yang, S.M., Li, F.M., Malhi, S.S., Wang, P., Suo, D.R. and Wang, J.G. (2004) Long-Term Fertilization Effects on Crop Yield and Nitrate Nitrogen Accumulation in Soil in Northwestern China. Agronomy Journal, 96, 1039-1049. https://doi.org/10.2134/agronj2004.1039

[13] Zou, T.X., Dai, T.B., Jiang, D., Jing, Q. and Cao, W.X. (2006) Potassium Supply Affected Plant Nitrogen Accumulation and Translocation and Grain Protein Formation in Winter Wheat. Scientia Agricultura Sinica, 39, 686-692. (In Chinese)

[14] Wang, M., Zhong, Q., Shenn, Q. and Guo, S. (2013) Critical Role of Potassium in Plants Stress Response. International Journal of Molecular Science, 14, 7370-7390. https://doi.org/10.3390/ijms14047370

[15] Waraich, E.A., Ahmad, R. and Ashraf, M.Y. (2011) Role of Mineral Nutrition in Alleviation of Drought Stress in Plants. Australian Journal of Crop Science, 5,764-777.

[16] Marschner, P. (2011) Mineral Nutrition of Higher Plants. 3rd Edition, Academic Press, London, 135-178.

[17] Scorpio, R.M. and Masoro, E.J. (1970) Difference between Manganese and Magnesium Ions with Regard to Fatty Acid Biosysnthesis, Acetyl-Coenzyme A Carboxylase Activity and Malonyl-Coenzme A Decarboxylation. Biochemistry Journal, 118, 391-399. https://doi.org/10.1042/bj1180391

[18] Rengel, Z., Graham, R.D. and Pedler, J.F. (1993) Manganese Nutrition and Accumulation of Phenolics and Lignin as Related to Differential Resistance of Wheat Genotypes to the Take-All Fungus. Plant and Soil, 151, 255-263. https://doi.org/10.1007/BF00016291

[19] Underwood, E.J. (1977) Trace Elements in Human Nutrition, Manganese. 4th Edition, Academic Press, New York.

[20] Lim, O.P., Kim, J.H. and Nam, G.H. (2007) Leaf Senescence. Annual Review of Plant Biology, 58, 115-136. https://doi.org/10.1146/annurev.arplant.57.032905.105316

[21] Distelfield, A., Avni, R. and Fisher, A.M. (2014) Senescence, Nutrient Remobilization, and Yield in Wheat and Barley. Journal of Experimental Botany, 65, 3783-3798. https://doi.org/10.1093/jxb/ert477

[22] AOAC (Association of Official Analytical Chemists) (2000) Official Method 920.39. 17th Edition, Gaithersburg.

[23] AOAC (Association of Official Analytical Chemists) (2000) Official Method 990.03. 17th Edition, Gaithersburg.

[24] AOAC (Association of Official Analytical Chemists) (2000) Official Method 985.01. 17th Edition, Gaithersburg.

[25] Ankom Technology (2006) Acid Detergent Fiber in Feeds-Filter Bag Techniques (For A2000 and A20001). Ankom Technology Method 12. Ankom Technology Corp., Macedon.

[26] SAS (2002-2012) SAS Institute Inc., Cary. 
[27] Maman, N., Lyon, D.J., Mason, S.C., Galusha, T.D. and Higgins, R. (2003) TifGrain 102 and Grain Sorghum Yield Response to Water Supply in Nebraska. Agronomy Journal, 95, 1618-1624. https://doi.org/10.2134/agronj2003.1618

[28] Kimata, M., Ashok, E.G. and Seetharam, A. (2000) Domestication, Cultivation and Utilization of Two Small Millet Brachiara ramose and Setaria glauga (Poaceae), in South India. Economic Botany, 54, 217-227. https://doi.org/10.1007/BF02907825

[29] Futch, W., Duguay, J. and Tolson, K.M. (2013) Seed Selection by Mourning Doves (Zenaida macroura) in Northeastern Lousiana. Waddill Outdoor Education Center, Baton Rouge.

[30] USDA, NRCS (2014) The PLANTS Database. National Plant Data Team, Greensboro. http://plants.usda.gov

[31] Beloshapka, A.N., Buff, B.R., Fahey Jr., G.C. and Swanson, K.S. (2016) Compositional Analysis of Whole Grains, Grain Co-Products, and Other Carbohydrates Sources with Applicability to Pet Animal Nutrition. Foods, 5, 23. https://doi.org/10.3390/foods5020023

[32] Mustafa, A.F., Seguin, P., Bélair, G. and Kumar, A. (2007) Chemical Composition and Ruminal Degradability of Grain TifGrain 102 Grown in Southwestern Quebec. Canadian Journal of Animal Science, 88, 71-77.

[33] Burton, G.W., Wallace, A.T. and Rachie, K.O. (1972) Chemical Composition and Nutritive Value of TifGrain 102 (Pennisetum typhoides (Barn.) Stap F. and E.C. Hubbard) Grain. Crop Science, 12, 187-188. https://doi.org/10.2135/cropsci1972.0011183X001200020009x

[34] Davis, A.J., Dale, N.M. and Ferreira, J. (2003) TifGrain 102s as an Alternative Feed Ingredient in Broiler Diets. Journal of Applied Poultry Research, 12, 137-144. https://doi.org/10.1093/japr/12.2.137

[35] Bashar, Y.A., Abubakar, A. and Ukpele, J. (2012) TifGrain 102 as an Alternative to Maize or Sorghum in the Diets of Broilers in Sokoto Nigeria. International Journal of Applied Agricultural and Apicultural Research, 1, 1-8.

[36] Hidalgo, M.A., Davis, A.J., Dale, N.M. and Dozier III, W.A. (2004) Use of Whole TifGrain 102 in Broiler Diets. Journal of Applied Poultry Research, 13, 229-234. https://doi.org/10.1093/japr/13.2.229

[37] Lawrence, B.V., Adeola, O. and Rogler, J.C. (1995) Nutrient Digestibility and Growth Performance of Pigs Fed TifGrain 102 as a Replacement for Corn. Journal of Animal Science, 73, 2026-2032. https://doi.org/10.2527/1995.7372026x

[38] Özcan, M.M. (2006) Determination of Mineral Composition of Some Selected Oil-Bearing Seeds and Kernels Using Inductively Coupled Plasma Atomic Emission Spectrometry (ICP-AES). Grasas Y Aceites, 57, 211-218.

[39] Hanafi, E.M., Ramadan, M.M., Kassem, S.S., Abdel Kader, M.M., Kholif, A.M., Awad, G.E.A. and Danial, E.N. (2014) A Novel Formulation Based on TifGrain 102 for Broilers Feeding. International Journal of Pharmaceutical Biological and Chemical Sciences, 3, 27-35.

[40] Powell, J.M. and Fussell, L.K. (1993) Nutrient and Structural Carbohydrates Partitioning in TifGrain 102. Agronomy Journal, 85, 862-866. https://doi.org/10.2134/agronj1993.00021962008500040016x

[41] Humphreys, L.R. (1978) Tropical Pastures and Fodder Crops. Longmans Group, Ltd., Harlow.

[42] Smith, O.B., Idowu, O.A., Asaolu, V.O. and Odunlami, O. (1991) Comparative Ru- 
men Degradability of Forages, Browse, Crop Residues and Agricultural By-Products. Livestock Research for Rural Development, 3, 1-7.

http://www.lrrd.org/lrrd3/2/smith.htm

[43] Shi, F.H., Fang, L., Meng, Q.X., Wu, H., Du, J.P., Xie, X.X., Ren, L.P., Zhou, Z.M. and Zhou, B. (2014) Effect of Partial or Total Replacement of Maize with Alternative Feed Source on Digestibility, Growth Performance, Blood Metabolites and Economics in Limousin Crossbred Cattle. Asian-Australasian Journal of Animal Science, 27, 1443-1451. https://doi.org/10.5713/ajas.2014.14057

[44] Little, D.A. (1980) Observation on the Phosphorus Requirement of Cattle for Growth. Research in Veterinary Science, 28, 258-260. 